\title{
Studi Perbandingan Respon Struktur Gedung Menggunakan Fluid Viscous Damper dengan Variasi Jumlah Lantai
}

\author{
AMATULHAY PRIBADI, ERMA DESMALIANA, \\ DIANDRA TIRA FADLISHA
}

\author{
Jurusan Teknik Sipil, Institut Teknologi Nasional Bandung \\ Email: amatulhay.p@itenas.ac.id
}

\begin{abstract}
ABSTRAK
Pendekatan teknologi dapat dilakukan dalam perencanaan struktur tahan gempa salah satunya yaitu dengan menggunakan Fluid Viscous Damper (FVD). Alat peredam FVD memiliki fungsi untuk menyerap energi gempa dan mengurangi gaya gempa rencana yang dipikul elemen-elemen struktur sehingga memungkinkan struktur bangunan menjadi lebih elastis. Penelitian ini bertujuan untuk mengetahui jumlah lantai yang paling efektif terhadap kinerja struktur portal beton dengan pola penempatan FVD yang paling baik untuk variasi jumlah lantai gedung yaitu 12, 16, dan 20 lantai. Metode yang digunakan yaitu analisis dinamis riwayat waktu dengan menggunakan software ETABS v.15.2.2. Hasil penelitian menunjukkan bahwa struktur gedung 12 lantai memberikan peningkatan respon struktur yang paling baik. Penggunaan FVD pada struktur 12 lantai mereduksi waktu getar alami struktur sebesar 49,75\%, meningkatkan gaya geser dasar hingga 28,87\%, dan mereduksi simpangan struktur baik akibat beban gempa respons spektra maupun beban time history.
\end{abstract}

Kata kunci: fluid viscous damper, metode riwayat waktu, waktu getar, gaya geser dasar, dan simpangan struktur

\begin{abstract}
Technological approach can be performed on earthquake-resistant structural design method, one of which is by using the Fluid Viscous Damper (FVD). The main function of FVD as a damper is to absorb seismic energy and reduce the seismic force which is carried by structural elements and thus the building structures become more elastic. This study aims to determine the most effective number of floors for the performance of reinforced concrete frames structure using best position of FVD with three floors variations, which are 12, 16, and 20 floors. The dynamic time history analysis method is tested using ETABS v.15.2.2 software. The results showed that the 12-story structure generates the best structural response. The installation of FVD on a 12-story structure reduces the natural period of structure by $49,75 \%$, increases the base shear force by $28,87 \%$, and reduces the drift of structure due to response spectrum load as well as time history loads.
\end{abstract}

Key words: fluid viscous damper, time history methods, structural period, base shear, and drift 


\section{PENDAHULUAN}

Perkuatan struktur bangunan terhadap beban gempa dapat dilakukan untuk mencegah terjadinya kerusakan bangunan. Umumnya kerusakan pada struktur diakibatkan oleh adanya simpangan antar lantai yang berlebih akibat pembebanan. Penambahan kekakuan bangunan dalam arah lateral dapat menjadi salah satu solusi untuk megurangi besarnya simpangan antar lantai. Namun, resiko yang dapat terjadi yaitu bangunan akan mengalami percepatan lantai yang besar akibat kekakuan lateral yang cukup besar.

Solusi lain untuk mengurangi resiko kerusakan bangunan akibat gempa yaitu dengan menggunakan alat peredam atau damper. Salah satu jenis alat peredam gempa yang banyak diaplikasikan pada struktur bangunan adalah Fluid Viscous Damper(FVD). FVD berfungsi untuk memperkecil respon simpangan struktur dan getaran yang timbul karena adanya beban dinamis. FVD dapat menyerap energi gempa dan mengurangi gaya gempa rencana yang akan dipikul oleh elemen-elemen struktur sehingga memungkinkan struktur bangunan untuk tetap bersifat elastis pada saat gempa terjadi dan mampu meredam guncangan gempa. Oleh karena itu, kerusakan struktur bangunan yang terjadi akibat beban gempa dapat dihindari. Tujuan dari penelitian ini untuk mengetahui jumlah lantai yang paling efektif terhadap kinerja struktur menggunakan FVD dengan pola penempatan paling baik menggunakan metode riwayat waktu.

\section{TINJAUAN PUSTAKA}

\subsection{Prinsip Sistem Fluid Viscous Damper(FVD)}

Proses pendisipasian energi dari FVD merupakan aplikasi dari konsep mekanika fluida pada fluid viscous yang menghasilkan gaya perlawanan melalui pergerakan yang dibatasi. Gaya yang diberikan oleh FVD tersebut memiliki besaran yang sebanding dengan kecepatan deformasinya.

Piston dalam silinder FVD bergerak dan mengalirkan cairan melalui lubang di kepala piston. Proses tersebut menghasilkan friksi yang dapat mengubah energi gempa menjadi energi panas. Besaran gaya bergantung pada ukuran dan bentuk dari lubang dan kekentalan cairan dari FVD. Skema pergerakan dari alat FVD dapat dilihat pada Gambar 1.

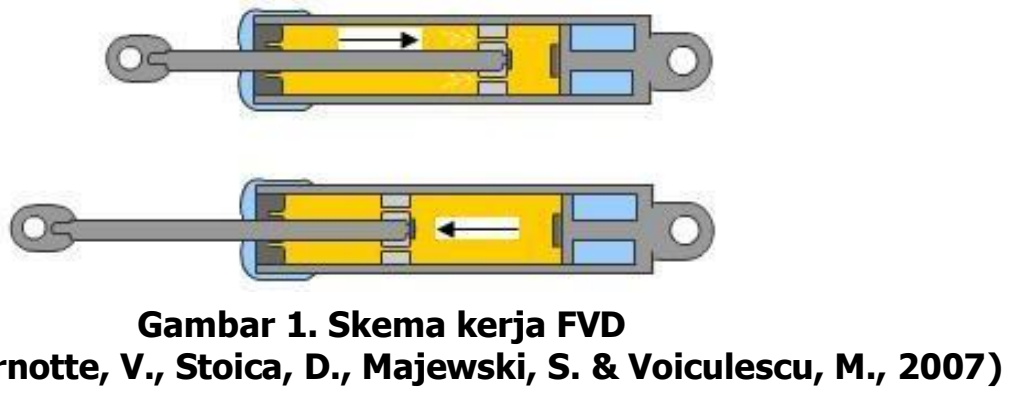

\subsection{Kekakuan pada Fluid Viscous Damper (FVD)}

Berdasarkan studi Hanif, A. N. (2018) menurut Douglas P. Taylor, rumus kekakuan dari Fluid Viscous Damper dihitung dengan Persamaan 1 sebagai berikut:

$$
K=\frac{A E}{L}
$$

halmana:

$$
\begin{array}{ll}
K & =\text { kekakuan FVD }[\mathrm{kg} / \mathrm{m}], \\
A & =\text { luas selimut FVD }\left[\mathrm{m}^{2}\right], \\
E & =\text { modulus elastisitas }\left[\mathrm{kg} / \mathrm{m}^{2}\right],
\end{array}
$$


$L \quad=$ panjang FVD $[\mathrm{m}]$.

\subsection{Gaya pada Fluid Viscous Damper}

Konsep penambahan peredam pada struktur mengasumsikan bahwa energi yang masuk ke dalam strutur akan diserap sebagian besar oleh elemen peredam (damper) dan sisa energi atau sebagian kecil diserap oleh elemen struktur lainnya. Fluid Viscous Damper mempunyai keunikan yaitu mampu memperkecil tegangan dan defleksi secara bersamaan. Hal ini dikarenakan gaya Fluid Viscous Damper bervariasi hanya dengan kecepatan geraknya, yang menghasilkan respon yang langsung berhubungan terhadap tegangan lentur struktur. Bentuk umum dari gaya redaman yang diinput untuk analisis struktur yang menggunakan Fluid Viscous Damper dapat dilihat pada Persamaan 2 berikut:

$$
F_{d}=C x^{\alpha}
$$

halmana:

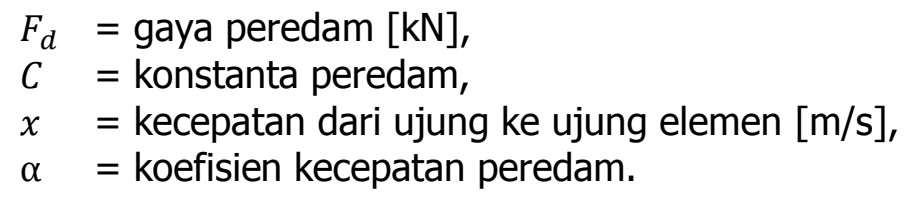

\subsection{Analisis Ragam Riwayat Waktu}

Pada Analisis Ragam Riwayat Waktu diperlukan rekaman percepatan gempa. Analisis dinamik riwayat waktu (time history) sangat cocok digunakan untuk analisis struktur yang tidak beraturan terhadap pengaruh gempa rencana. Mengingat gerakan tanah akibat gempa di suatu lokasi sulit diperkirakan dengan tepat, maka sebagai input gempa dapat didekati dengan gerakan tanah yang disimulasikan.

\subsection{Studi Penelitian Terdahulu}

Penelitian ini disusun dengan dasar dari beberapa studi yang pernah dilakukan sebelumnya yang digunakan sebagai bahan perbandingan dan kajian. Studi terdahulu dapat dilihat pada Tabel 1.

Tabel 1. Studi Terdahulu

\begin{tabular}{|c|c|c|c|c|c|}
\hline No. & Peneli & & Judul Penelitian & $\begin{array}{c}\text { Metode } \\
\text { Penelitian }\end{array}$ & Hasil Penelitian \\
\hline 1. & $\begin{array}{l}\text { Naurah } \\
\text { (Universitas } \\
\text { Sumatera } \\
\text { 2015) }\end{array}$ & $\begin{array}{l}\text { Nazifa } \\
\text { Utara, }\end{array}$ & $\begin{array}{l}\text { Analisis Pengaruh } r \text { Pola } \\
\text { Penempatan Fluid Viscous } \\
\text { Damper terhadap Respon } \\
\text { Struktur Gedung Akibat Gaya } \\
\text { Gempa }\end{array}$ & $\begin{array}{l}\text { Metode Ragam } \\
\text { Riwayat Waktu }\end{array}$ & $\begin{array}{l}\text { Hasil dari penelitian ini adalah } \\
\text { mendapatkan pola } \\
\text { penempatan FVD yang terbaik } \\
\text { untuk gedung } 12 \text { lantai. }\end{array}$ \\
\hline
\end{tabular}

\section{METODE PENELITIAN}

Langkah awal yang dilakukan dalam penelitian ini adalah mengidentifikasi masalah dan menentukan topik serta melakukan tinjauan pustaka yang akan digunakan sebagai dasar anilisis atau perhitungan yang dilakukan. Tahap selanjutnya menentukan layout dan dimensi gedung, kemudian melakukan preliminary design yang dilakukan dengan cara trial and error. Tahap selanjutnya yaitu memasukkan data struktur dan pembebanan pada software ETABS v.15.2.2. Setelah seluruh data yg dibutuhkan sudah memenuhi, dilakukan pemodelan gedung dengan 3 variasi jumlah lantai, yaitu 12 lantai, 16 lantai dan 20 lantai. Analisis struktur yang dilakukan yaitu periode struktur, gaya geser dasar, simpangan antar lantai dan modal partisipasi massa. Jika hasil dari pengecekan (running) ternyata model struktur tidak 
memenuhi syarat, maka dilakukan preliminary design kembali. Namun, jika hasil dari pengecekan (running) tersebut sudah memenuhi syarat, maka dilanjutkan dengan analisis dan pembahasan. Berdasarkan hasil analisis tersebut dapat diperoleh kesimpulan dan saran.

\section{HASIL ANALISIS DAN PEMBAHASAN}

\subsection{Perencanaan Struktur}

Data perencanaan struktur yang digunakan dalam penelitian ini antara lain sebagai berikut:

1. Struktur berada di Kota Aceh.

2. Fungsi bangunan adalah perkantoran.

3. Struktur memiliki ketinggian tiap lantainya $4 \mathrm{~m}$.

4. Struktur merupakan Sistem Rangka Pemikul Momen Khusus (SRPMK) beron bertulang.

5. Mutu beton yang digunakan adalah $f_{c}^{\prime}=25 \mathrm{MPa}$.

6. Mutu baja tulangan yang digunakan adalah $f_{y}=400 \mathrm{MPa}$.

\subsection{Preliminary Design}

Dimensi balok yang digunakan pada struktur bangunan ini adalah sebagai berikut:
(a) balok arah $\mathrm{X}$
$=500 \times 600 \mathrm{~mm}$;
(b) balok arah $Y$
$=400 \times 500 \mathrm{~mm}$.

Dimensi kolom yang digunakan pada struktur bangunan ini adalah sebagai berikut:
(a) lantai 1-2
$=1000 \times 1000 \mathrm{~mm}$;
(b) lantai 3-4
$=800 \times 800 \mathrm{~mm}$;
(c) lantai 5-6
$=750 \times 750 \mathrm{~mm}$;
(d) lantai 7-8
$=700 \times 700 \mathrm{~mm}$;
(e) lantai 9-10
$=650 \times 650 \mathrm{~mm}$;
(f) lantai $11-12$
$=600 \times 600 \mathrm{~mm}$;
(g) lantai 13-14
$=550 \times 550 \mathrm{~mm}$;
$=500 \times 500 \mathrm{~mm}$;
$=450 \times 450 \mathrm{~mm}$;
(i) lantai $17-18$
$=400 \times 400 \mathrm{~mm}$.

Dimensi pelat yang digunakan pada struktur bangunan ini adalah sebagai berikut:
(a) pelat lantai
$=120 \mathrm{~mm}$;
(b) pelat atap
$=100 \mathrm{~mm}$.

Denah struktur bangunan dapat dilihat pada Gambar 2.

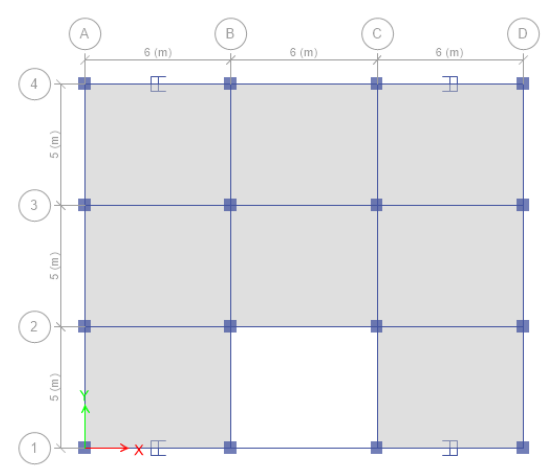

Gambar 2. Denah struktur bangunan 
4.3 Perencanaan Fluid Viscous Damper pada Struktur Gedung

Pada penelitian ini, struktur bangunan gedung menggunakan 2 tipe FVD, yaitu FVD-750 dan FVD-1500. FVD pada arah X-Z memiliki panjang $(L)$ 7,211 m dan FVD pada arah Y-Z memiliki panjang $(L)$ 6,4031 m. Spesifikasi Fluid Viscous Damper dapat dilihat pada Tabel 2.

Tabel 2. Spesifikasi Fluid Viscous Damper

\begin{tabular}{ccccccc}
\hline Tipe FVD & $\begin{array}{c}\boldsymbol{d} \\
{[\mathbf{m}]}\end{array}$ & $\begin{array}{c}\text { Berat } \\
{[\mathbf{k g}]}\end{array}$ & $\begin{array}{c}\boldsymbol{F} \\
{[\mathbf{k N}]}\end{array}$ & $\begin{array}{c}\boldsymbol{x} \\
{[\mathbf{m} / \mathbf{s}]}\end{array}$ & $\boldsymbol{\alpha}$ & $\begin{array}{c}\boldsymbol{E} \\
{\left[\mathbf{k g} / \mathbf{m}^{2}\right]}\end{array}$ \\
\hline FVD-750 & 0,184 & 168 & 750 & 1,2 & 0,45 & $2 \times 10^{10}$ \\
\hline FVD-1500 & 0,245 & 306 & 1.500 & 1,2 & 0,45 & $2 \times 10^{10}$ \\
\hline
\end{tabular}

halmana:

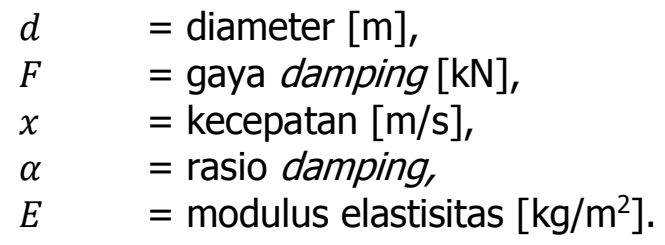

Pada penelitian ini, damper dipasang pada dua bentang tepi namun dengan arah diagonal berlawanan. Penempatan damper pada arah sumbu $X$ dipasang di setiap lantai ganjil seperti pada Gambar 3, sedangkan pada arah sumbu $Y$ dipasang di setiap lantai genap seperti pada Gambar 4.

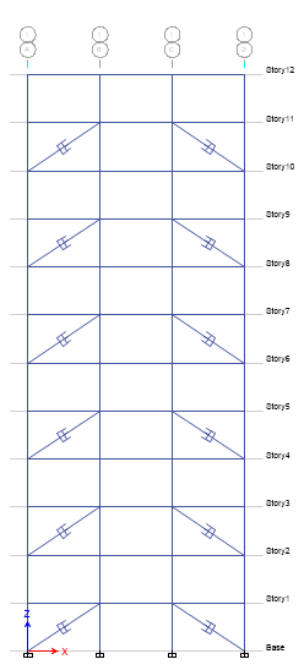

Gambar 3. Potongan Arah Sumbu X untuk Struktur Gedung 12 Lantai

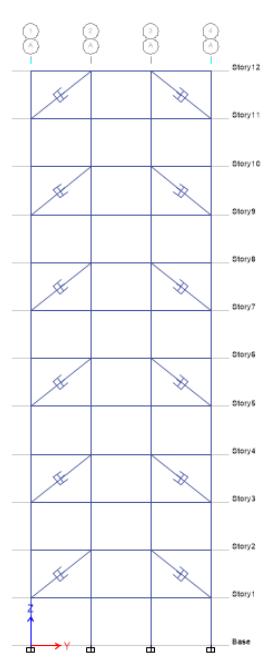

\section{Gambar 4. Potongan Arah Sumbu $Y$ untuk Struktur Gedung 12 Lantai}

\subsection{Analisis Struktur}

Analisis struktur yang dilakukan dalam penelitian ini yaitu menentukan nilai periode struktur, gaya geser dasar, simpangan antar lantai, modal partisipasi massa, gaya dalam elemen struktur dan P-M-M rasio kolom.

\subsubsection{Periode Struktur}

Periode atau waktu getar struktur adalah waktu bergetar dan bergoyangnya struktur dalam satu periode. Waktu getar struktur harus memenuhi persyaratan supaya kondisi struktur tidak terlalu fleksibel. Berdasarkan analisis menggunakan software ETABS v.15.2.2. didapatkan hasil periode struktur seperti pada Gambar 5. 


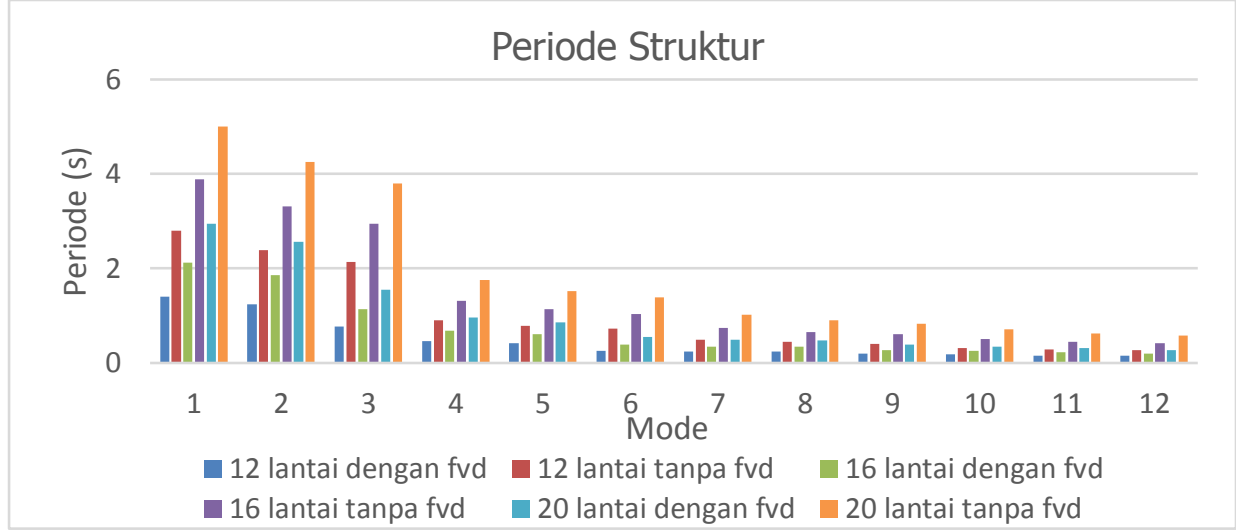

Gambar 5. Grafik periode struktur

\subsubsection{Gaya Geser Dasar}

Gaya geser dasar akan didistribusikan secara vertikal sepanjang tinggi struktur sebagai gaya horizontal tingkat yang bekerja pada masing-masing tingkat bangunan dengan menjumlahkan gaya horizontal pada tingkat-tingkat yang ditinjau. Hasil analisis gaya geser dasar dapat dilihat pada Tabel $\mathbf{3}$ untuk gaya geser dasar arah X dan Tabel $\mathbf{4}$ untuk gaya geser dasar arah $\mathrm{Y}$.

Tabel 3. Gaya geser dasar arah $\mathbf{X}$

\begin{tabular}{lcccccc}
\hline \multirow{2}{*}{ Gempa Acuan } & \multicolumn{9}{c}{ FX [kN] } \\
\cline { 2 - 7 } & \multicolumn{2}{c}{$\mathbf{1 2}$ Lantai } & \multicolumn{2}{c}{$\mathbf{1 6}$ Lantai } \\
Tanpa & $\begin{array}{c}\text { Dengan } \\
\text { FVD }\end{array}$ & $\begin{array}{c}\text { Tanpa } \\
\text { FVD }\end{array}$ & $\begin{array}{c}\text { Dengan } \\
\text { FVD }\end{array}$ & $\begin{array}{c}\text { Tanpa } \\
\text { FVD }\end{array}$ & $\begin{array}{c}\text { Lantai } \\
\text { Dengan } \\
\text { FVD }\end{array}$ \\
\hline Gempa El-Centro & 343,490 & 503,154 & 234,8303 & 413,239 & 151,529 & 539,386 \\
\hline Gempa Chichi & 2,373 & 2,404 & 3,104 & 3,157 & 3,694 & 3,811 \\
\hline $\begin{array}{l}\text { Gempa Loma } \\
\text { Prieta }\end{array}$ & 0,123 & 0,148 & 0,153 & 0,174 & 0,178 & 0,199 \\
\hline Respon Spektrum & $1.186,872$ & $2.067,2813$ & $1.118,397$ & $1.934,812$ & $1.055,774$ & $1.824,763$ \\
\hline
\end{tabular}

Tabel 4. Gaya geser dasar arah $Y$

\begin{tabular}{lcccccc}
\hline \multirow{2}{*}{ Gempa Acuan } & \multicolumn{9}{c}{ FY [kN] } \\
\cline { 2 - 7 } & \multicolumn{2}{c}{ 12 Lantai } & \multicolumn{2}{c}{$\mathbf{1 6}$ Lantai } & \multicolumn{2}{c}{ 20 Lantai } \\
\cline { 2 - 7 } & $\begin{array}{c}\text { Tanpa } \\
\text { FVD }\end{array}$ & $\begin{array}{c}\text { Dengan } \\
\text { FVD }\end{array}$ & $\begin{array}{c}\text { Tanpa } \\
\text { FVD }\end{array}$ & $\begin{array}{c}\text { Dengan } \\
\text { FVD }\end{array}$ & $\begin{array}{c}\text { Tanpa } \\
\text { FVD }\end{array}$ & $\begin{array}{c}\text { Dengan } \\
\text { FVD }\end{array}$ \\
\hline Gempa El-Centro & 271,225 & 373,711 & 140,825 & 516,718 & 120,8314 & 556,323 \\
\hline Gempa Chichi & 2,352 & 2,401 & 3,053 & 3,105 & 3,619 & 3,743 \\
\hline $\begin{array}{l}\text { Gempa Loma } \\
\text { Prieta }\end{array}$ & 0,122 & 0,158 & 0,147 & 0,169 & 0,183 & 0,197 \\
\hline Respon Spektrum & $1.031,582$ & $1.848,661$ & 969,951 & $1.773,321$ & 908,194 & 1.609644 \\
\hline
\end{tabular}

\subsubsection{Simpangan Antar Lantai}

Hasil simpangan antar lantai (storydrift) pada ketiga model struktur gedung dengan FVD mengalami penurunan baik akibat beban gempa respon spektra maupun akibat tiga beban gempa time history. Hasil analisis simpangan antar lantai untuk struktur gedung 12 lantai dapat dilihat pada Gambar 7 dan Gambar 8. 


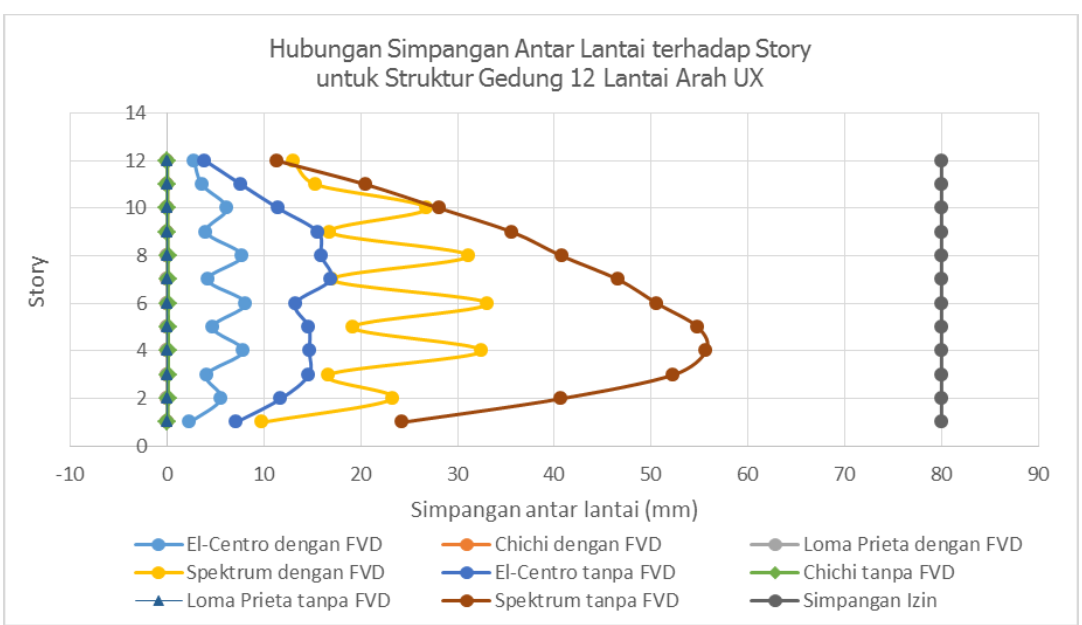

Gambar 7. Grafik simpangan antar lantai struktur gedung 12 lantai arah UX

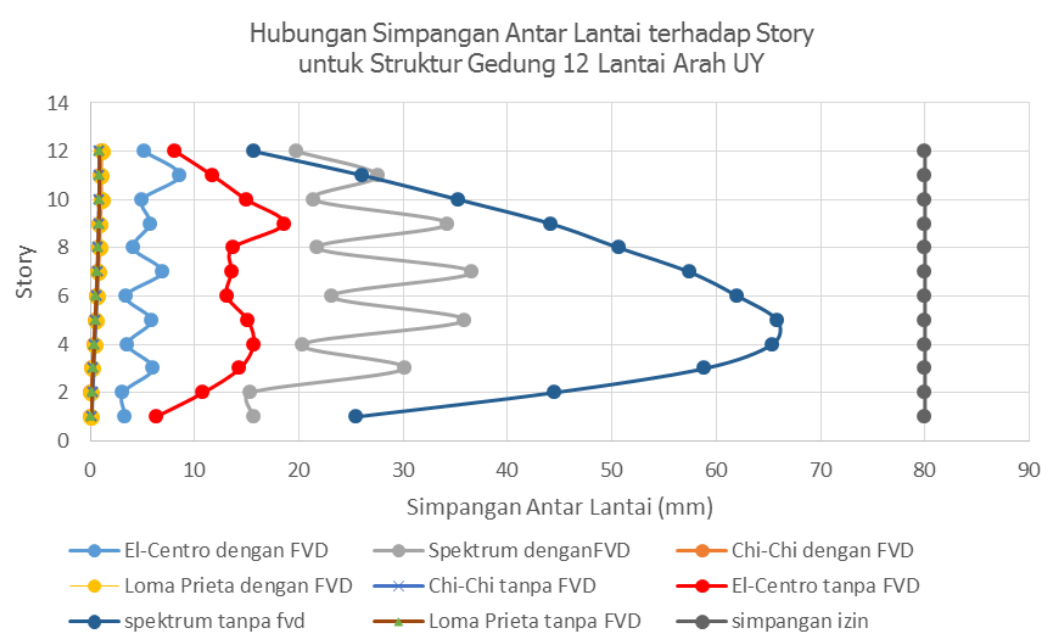

Gambar 8. Grafik simpangan antar lantai struktur gedung 12 lantai arah UY

Hasil analisis simpangan antar lantai untuk struktur gedung 16 lantai dapat dilihat pada Gambar 9 dan Gambar 10.

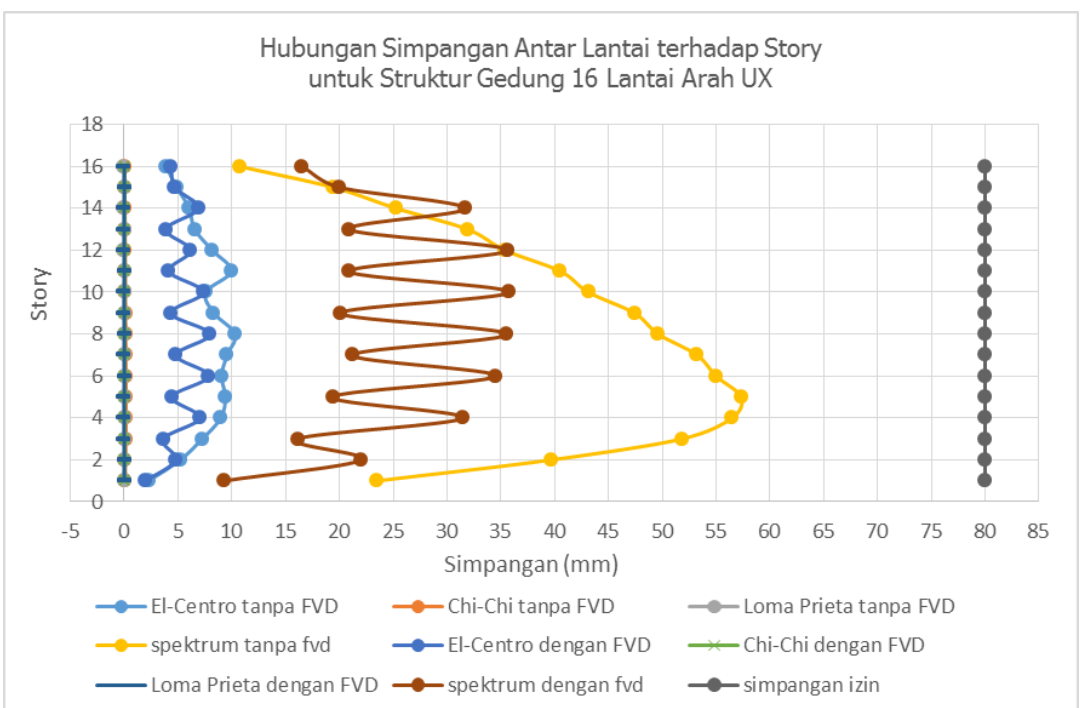

Gambar 9. Grafik simpangan antar lantai struktur gedung 16 lantai arah UX

RekaRacana: Jurnal Tenik Sipil - 28 


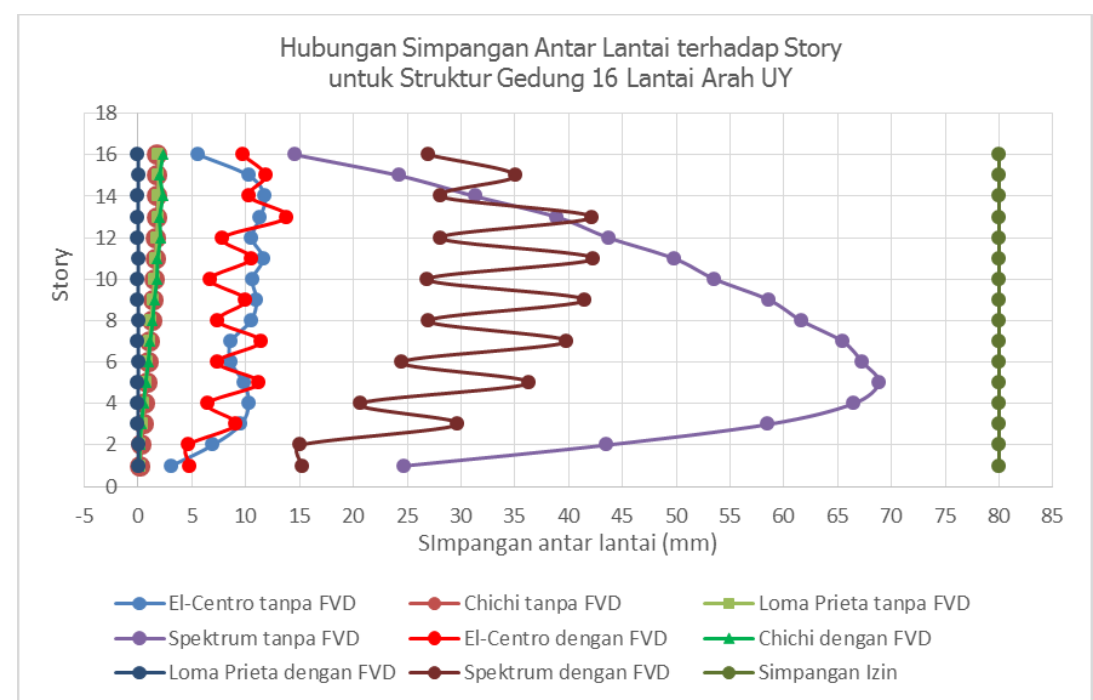

Gambar 10. Grafik simpangan antar lantai struktur gedung 16 lantai arah UY

Hasil analisis simpangan antar lantai untuk struktur gedung 20 lantai dapat dilihat pada Gambar 11 dan Gambar 12.

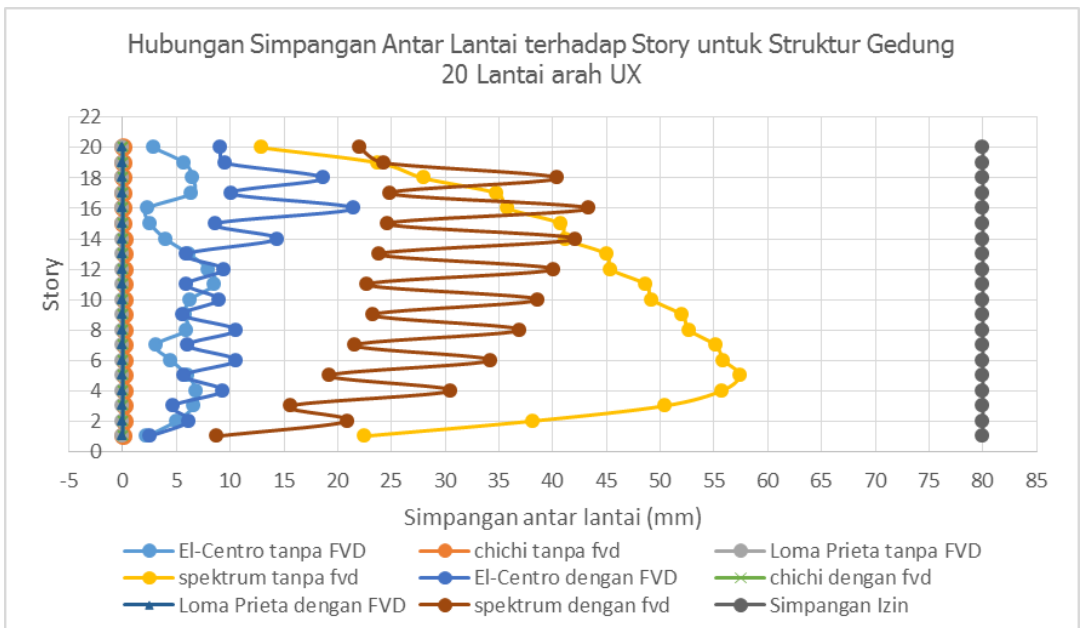

Gambar 11. Grafik simpangan antar lantai struktur gedung 20 lantai arah UX

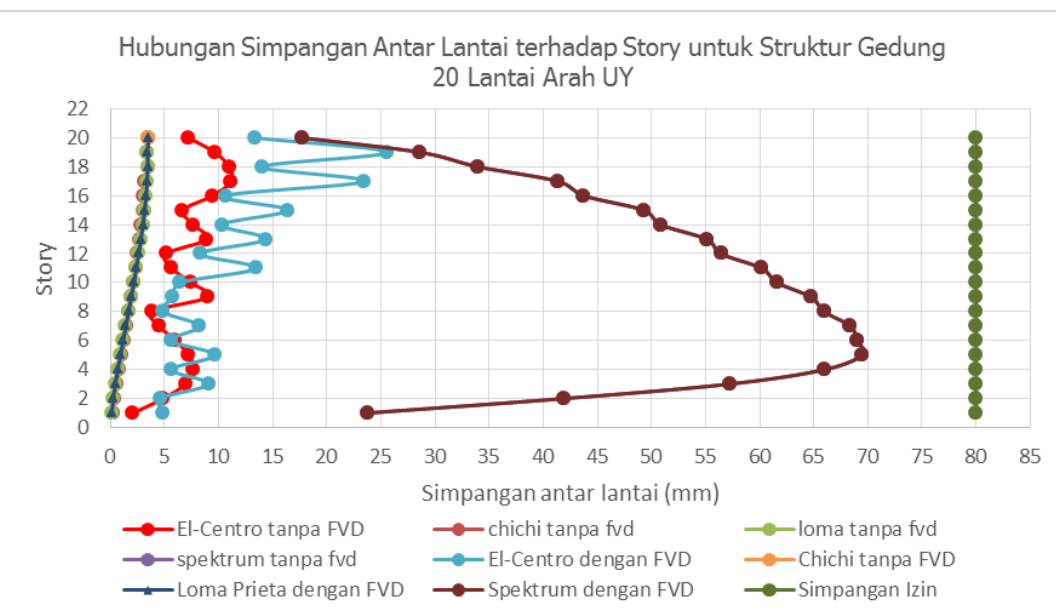

Gambar 12. Grafik simpangan antar lantai struktur gedung 20 lantai arah UY 
Pada struktur gedung yang menggunakan analisis time history dengan gempa acuan yaitu Gempa Chichi dan Gempa Loma Prieta, simpangan antar lantai yang terjadi sangatlah kecil. Sehingga, kurva yang terlihat pada grafik sangat berhimpit. Sedangkan pada struktur gedung yang menggunakan analisis time history dengan gempa acuan yaitu Gempa El-Centro memiliki pola grafik yang mirip dengan struktur gedung yang menggunakan analisis respon spektrum.

\subsubsection{Modal Partisipasi Massa}

Berdasarkan SNI 1726:2012 pasal 7.9.1 jumlah ragam untuk menentukan ragam getar alami bagi struktur harus cukup untuk mendapatkan partisipasi masa ragam terkombinasi paling sedikit sebesar $90 \%$ dari masa aktual pada arah X dan arah Y. Berdasarkan perhitungan dari ETABS v.15.2.2 didapatkan periode alami struktur dan modal partisipasi massa yang diperoleh dari 12 mode shapes pada Gambar 13.

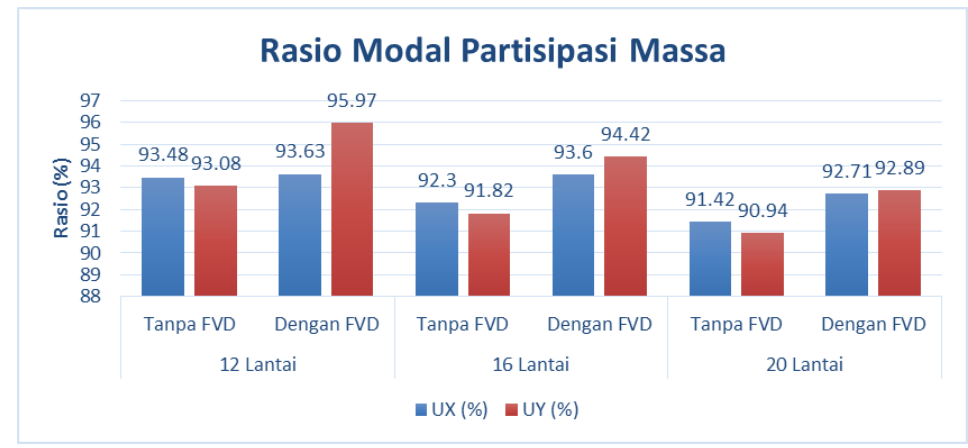

Gambar 13. Rasio modal partisipasi massa

\subsubsection{Gaya Dalam Elemen Struktur}

Elemen struktur terdiri dari balok sebagai elemen horizontal dan kolom sebagai elemen vertikal gedung. Berdasarkan hasil analisis dapat diperoleh bahwa terjadi penurunan gaya dalam momen lentur balok dan kolom pada struktur gedung yang menggunakan FVD akibat beban gempa respons spectra maupun beban gempa time history. Sedangkan untuk gaya aksial tekan pada kolom struktur gedung dengan FVD mengalami kenaikan dibandingkan tanpa FVD. Gaya dalam yang bekerja pada elemen struktur balok dapat dilihat seperti pada Gambar 14 dan gaya dalam pada kolom dapat dilihat pada Gambar 15.

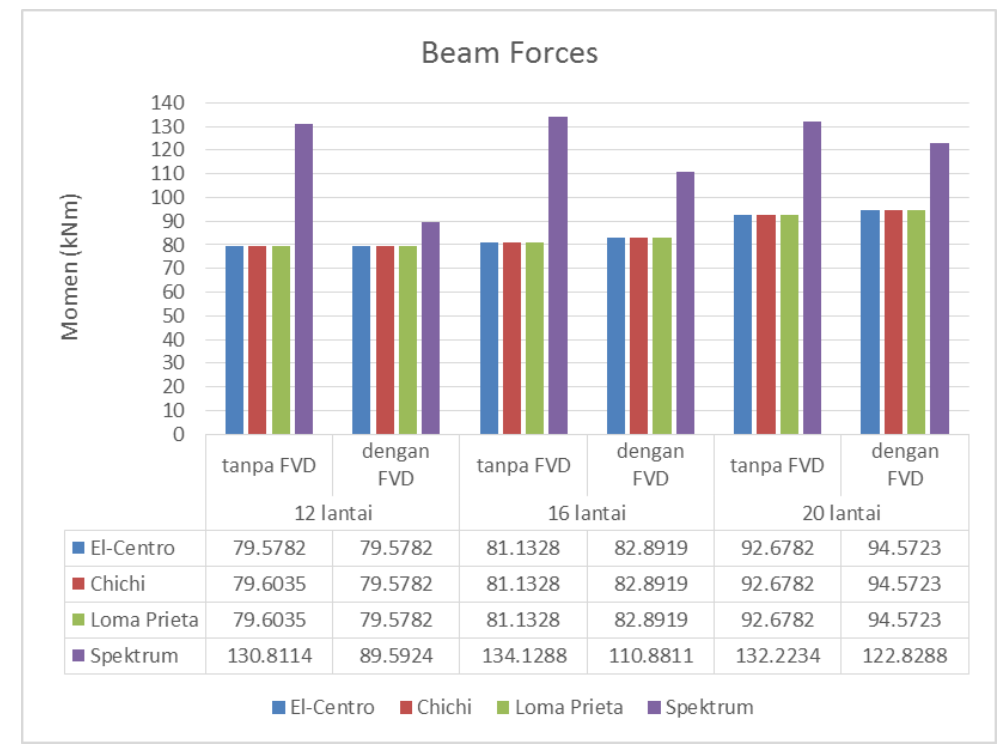

Gambar 14. Gaya dalam pada balok

RekaRacana: Jurnal Tenik Sipil - 30 


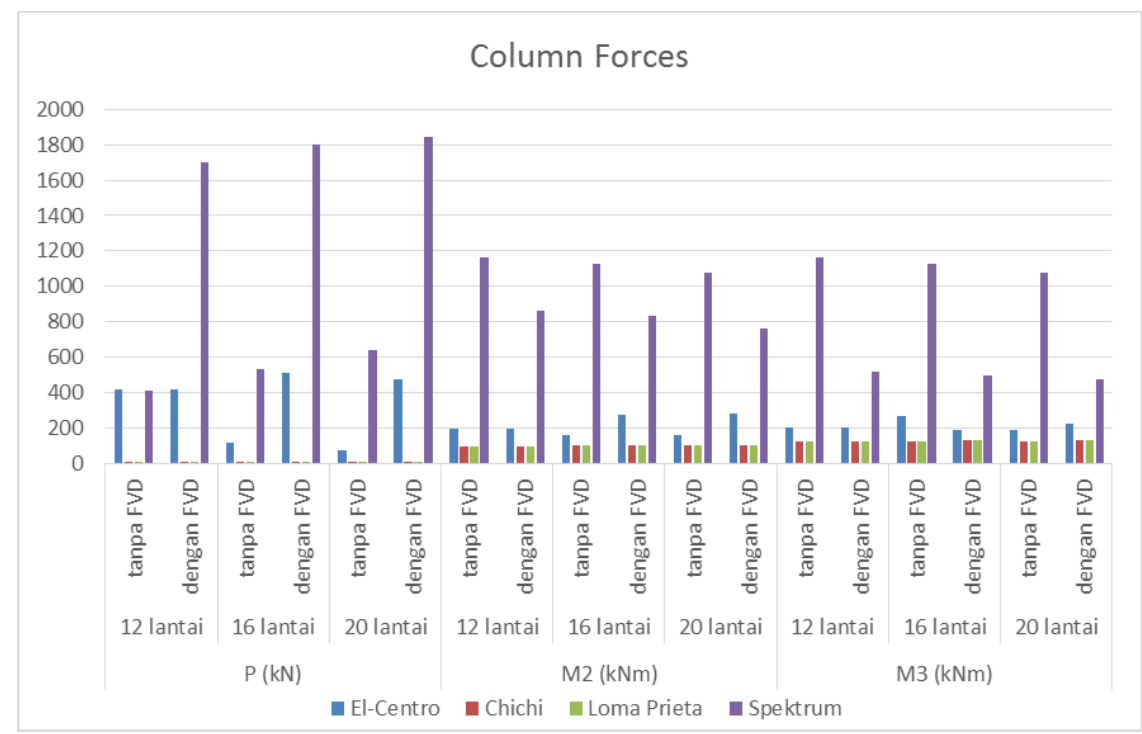

Gambar 15. Gaya dalam pada kolom

\subsubsection{P-M-M Rasio Kolom}

P-M-M rasio untuk suatu kolom pada struktur harus bernilai lebih kecil dari satu. Apabila nilai P-M-M besar atau sama dengan satu maka struktur telah mengalami defisiensi kekuatan/kapasitas dalam menahan beban kombinasi. Dengan kata lain, dapat dikatakan kolom mengalami overstress. Hasil P-M-M rasio kolom dapat dilihat pada Gambar 16.

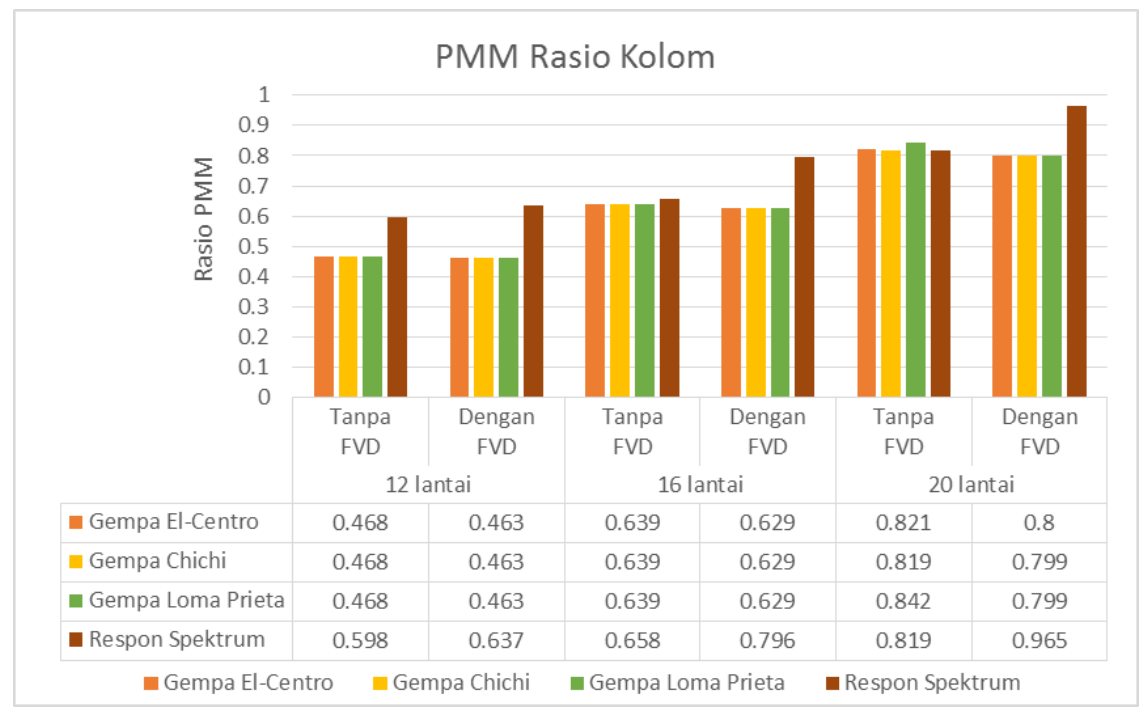

Gambar 16. Nilai P-M-M rasio kolom

\section{KESIMPULAN}

Berdasarkan hasil analisis yang telah dilakukan untuk ketiga model gedung terhadap beban respon spektra serta empat beban time history, dapat diambil kesimpulan sebagai berikut:

1. Periode getar alami struktur dengan menggunakan FVD mengalami penurunan hingga $49,75 \%$ pada struktur gedung 12 lantai; 45,51\% pada struktur gedung 16 lantai; dan $41,08 \%$ pada struktur gedung 20 lantai. Hal ini menyebabkan struktur gedung yang menggunakan FVD lebih kaku saat terjadi gempa bumi.

2. Penggunaan FVD dapat meningkatkan gaya geser dasar yang terjadi sebesar $28,79 \%$ untuk struktur gedung 12 lantai, 28,87\% untuk struktur gedung 16 lantai, dan 24,41\% untuk struktur gedung 20 lantai. 
3. Simpangan antar lantai maksimum yang terjadi pada struktur dengan FVD mengalami penurunan yaitu menjadi 36,608 mm pada struktur gedung 12 lantai; 42,328 mm pada struktur gedung 16 lantai; dan 53,0255 mm pada struktur gedung 20 lantai. Seluruh model struktur gedung sudah memenuhi persyaratan simpangan antar lantai izin maksimum yaitu $80 \mathrm{~mm}$.

4. Berdasarkan analisis yang dilakukan, terdapat peningkatan jumlah partisipasi massa untuk arah translasi horizontal sumbu $X$ dan sumbu $Y$ pada struktur gedung menggunakan FVD. Dapat disimpulkan bahwa struktur gedung dengan FVD membutuhkan waktu yang lebih singkat dibandingkan tanpa FVD, dalam mencapai faktor partisipasi modal sesuai peraturan yaitu minimal $90 \%$.

5. Penggunaan FVD pada struktur gedung menghasilkan nilai $\mathrm{P}-\mathrm{M}-\mathrm{M}$ rasio kolom yang memenuhi persyaratan yaitu tidak melebihi 1 . Nilai P-M-M rasio kolom terbesar yaitu pada struktur gedung 12 lantai 0,637; pada struktur gedung 16 lantai yaitu 0,796; dan pada struktur gedung 20 lantai yaitu 0,965.

6. Hasil analisis diatas menyimpulkan bahwa respon struktur gedung 12 lantai dengan pola FVD ini merupakan yang paling baik dibandingkan pada struktur gedung 16 lantai dan 20 lantai.

\section{DAFTAR RUJUKAN}

Badan Standardisasi Nasional. (2012). SNI 1726:2012 tentang Tata Cara Perencanaan Ketahanan Gempa untuk Struktur Bangunan Gedung dan Non Gedung. Jakarta: Badan Standardisasi Nasional.

Hanif, A. N. (2018). Kajian Kinerja Struktur Gedung Simetris Menggunakan Peredam Tipe Fluid Viscous Damper. 14.

Nazifa, N. (2015). Analisa Pengaruh Pola Penempatan Fluid Viscous Damper Terhadap Respon Struktur Gedung Akibat Gaya Gempa. Medan: Universitas Sumatera Utara.

Warnotte, V., Stoica, D., Majewski, S. \& Voiculescu, M. (2007). State of the art in the pounding mitigation techniques. Intersectii/Intersections "Structural Mechanics", 4(3), 102-117. 